\title{
REN wt Allele
}

National Cancer Institute

\section{Source}

National Cancer Institute. REN wt Allele. NCI Thesaurus. Code C113590.

Human REN wild-type allele is located in the vicinity of $1 \mathrm{q} 32$ and is approximately $12 \mathrm{~kb}$ in length. This allele, which encodes renin protein, is involved in ang iotensin activation and blood pressure homeostasis. Mutations in this gene are associated with both familial juvenile hyperuricemic nephropathy 2 and renal tubular dysgenesis. 